\title{
Helena Szewczyk*
}

\section{Partycypacja pracownicza przyszłością zbiorowego prawa pracy}

1. Przedmiotem partycypacji $\mathrm{w}$ zarządzaniu zakładem pracy są decyzje zapadające $\mathrm{w}$ przedsiębiorstwie $\mathrm{w}$ sprawach gospodarczych i pracowniczych ${ }^{1}$. Przyjmuje się, że jest to zarówno udział w podejmowaniu decyzji ściśle gospodarczych, jak i decyzji w kwestiach organizacji pracy, zatrudnienia czy w sprawach socjalnych ${ }^{2}$. Partycypacja odnosi się zatem do płaszczyzn gospodarczo-ekonomicznej, prawno-organizacyjnej oraz pracowniczo-socjalnej. Wśród licznych argumentów natury ekonomicznej, społecznej i etycznej wymienionych w doktrynie ${ }^{3}$, uzasadniających istnienie prawa do partycypacji pracowników, należy w szczególności podkreślić, że uczestnictwo pracowników w zarządzaniu zakładem pracy jest jedną $\mathrm{z}$ istotnych płaszczyzn upodmiotowienia ludzi $\mathrm{w}$ środowisku pracy. Z badań empirycznych wynika, że zachodzi ścisły związek pomiędzy stopniem ich uczestnictwa a wzrostem ich motywacji i zaangażowania w sprawy przedsiębiorstwa, zwiększeniem ich kreatywności i aktywności, co w efekcie przekłada się na wzrost wydajności (produktywności), jakości ich pracy oraz efektywności działania całego przedsiębiorstwa ${ }^{4}$. Wpływa to znacząco na redukcję kosztów działalności przedsiębiorstw, których znaczną część stanowią koszty pracy ${ }^{5}$.

* Dr hab., Katedra Prawa Pracy i Polityki Socjalnej, Wydział Prawa i Administracji Uniwersytetu Śląskiego.

${ }^{1}$ Por. J. Wratny, Problemy partycypacji przedstawicielskiej, [w:] Prawo pracy RP w obliczu przemian, red. M. Matey-Tyrowicz, T. Zieliński, Warszawa 2006, s. 512 i nast.

2 Podobnie T. Liszcz, Prawo pracy, Warszawa 2009, s. 535.

${ }^{3}$ Por. m.in. M. Smusz-Kulesza, Zbiorowe prawo pracowników do informacji, Warszawa 2012, s. 33 i nast.

${ }_{4}$ Zob. J. Piwowarczyk, Partycypacja w zarzadzaniu a motywowanie pracowników, Kraków 2006, s. 125 i nast.

${ }_{5}$ Zob. M. Juchnowicz, Partycypacja jako narzedzie polityki personalnej, [w:] Zarzadzanie pracownikami: instrumenty polityki personalnej, red. K. Makowski, Warszawa 2001, s. 146 i nast. 
Przyjęte rozwiązania prawne $\mathrm{w}$ tym zakresie powinny zapewniać równowagę stron oraz ochronę podstawowych interesów pracowników i pracodawców. Bezpośrednim celem współdziałania partnerów społecznych jest bowiem dobro przedsiębiorstwa jako dobro wspólne. Realizowane $\mathrm{w}$ ten sposób współdziałanie ma służyć również interesom pracowników, ale w ścisłym powiązaniu z interesem pracodawcy. Celem współpracy jest bowiem optymalizacja decyzji z uwzględnieniem interesów pracowniczych, a nie tylko reprezentowanie tych interesów.

2. Po II wojnie światowej zasada udziału pracowników w zarządzaniu przedsiębiorstwami stała się podstawowym składnikiem ustroju zakładów pracy nie tylko w krajach kapitalistycznych ${ }^{6}$. Udział załóg w zarządzaniu zakładami pracy realizowany był w końcu wieku XX w trzech podstawowych formach organizacyjnych:

1) za pośrednictwem związków zawodowych odgrywających podwójną rolę: przedstawicielstwa załogi oraz zrzeszenia powołanego do obrony zawodowych interesów swych członków;

2) odrębnych organów załogi przedsiębiorstwa wybieranych przez pracowników;

3) rokowań zbiorowych zapewniających stronie reprezentującej pracowników określony wpływ na działalność ekonomiczną i socjalną przedsiębiorstwa7.

W europejskich krajach o najbardziej postępowym ustroju pracy partycypacja pracownicza przerodziła się $\mathrm{w}$ tzw. partycypację dopuszczającą pracowników do współzarządzania zakładem pracy, czyli do współdecydowania oraz do udziału w zyskach.

Pojęcie partycypacji (zarządzania zakładem pracy) należy zatem obecnie rozumieć szeroko nie tylko jako udział pracowników w procesach decyzyjnych, ale również jako ich udział w wypracowanych efektach (w tym partycypacja finansowa, czyli kapitałowa wraz z akcjonariatem pracowniczym). Partycypacja kapitałowa opiera się przede wszystkim na własności udziałów lub akcji firmy należących do pracowników, którzy korzystają w ten sposób z przysługujących im praw majątkowych, takich jak prawo do udziału w zysku, oraz korporacyjnych.

Jedną z podstawowych zasad prawa pracy w Polsce jest zasada uczestnictwa osób zatrudnionych w zarządzaniu zakładem pracy. W literaturze prawa pracy zauważa się, że jest to podstawa nowej filozofii w dziedzinie zatrudnienia. Zakłada ona zmianę pozycji osoby zatrudnionej wobec pod-

${ }^{6}$ Por. M. Seweryński, Perspektywy partycypacji pracowników w zarządzaniu przedsiębiorstwem w krajach zachodnich, "Studia Prawno-Ekonomiczne” [Łódź] 1992, nr 46, s. 7-32; K. Wojtaszczyk, Partycypacja pracowników w zarządzaniu. Model austriacki i zachodnioniemiecki, Warszawa 1982, s. 7-43.

7 Zob. T. Zieliński, Prawo pracy. Zarys systemu, t. III, Warszawa-Kraków 1986, s. 321. 
miotu zatrudniającego. Z woli strony przekształca się ona we współpartnera, który poprzez swoich reprezentantów ma prawo do konsultacji ${ }^{8}$, wyrażania własnych propozycji i współuczestnictwa w podejmowaniu decyzji ${ }^{9}$. Uprawnienia pracowników $\mathrm{w}$ ramach partycypacji można podzielić na mocniejsze, stanowiące (współdecydowanie) oraz słabsze informacyjno-konsultacyjne ${ }^{10}$.

Zasada partycypacji pracowników w zarządzaniu zakładem pracy to jeden z filarów prawa pracy w Unii Europejskiej, stanowiący przejaw upodmiotowienia pracowników w stosunkach pracy poprzez aktywny bądź pasywny ich udział $w$ zarządzaniu zakładem pracy jako jedna z form dialogu i współpracy partnerów społecznych ${ }^{11}$. W świetle art. 153 ust. 2 Traktatu o funkcjonowaniu Unii Europejskiej ${ }^{12}$ jednym z głównych celów Unii jest bowiem wspieranie zaangażowania pracowników w działalność przedsiębiorstw, w których wykonują oni swą pracę.

Zawarte w art. 20 konstytucji RP oraz w ogólnej podstawowej zasadzie prawa pracy (art. 182 k.p.) prawa pracowników do partycypacji mogą być przede wszystkim realizowane $\mathrm{w}$ formach zinstytucjonalizowanych albo wynikać z praw korporacyjnych we wszystkich zakładach pracy, niezależnie od formy własności. Stąd możemy wyróżnić partycypację formalną (uregulowaną) oraz partycypację nieformalną (nieuregulowaną).

Należy przyjąć, że intencją ustawodawcy wyrażoną w tym przepisie było objęcie zakresem przedmiotowym pojęcia „partycypacji pracowniczej" wszystkich form zaangażowania pracowników w działalność przedsiębiorstwa ${ }^{13}$. Trzeba zatem definiować partycypację pracowniczą jako działalność pracowników obejmującą wszelkie formy uczestniczenia $\mathrm{w}$ procesach decyzyjnych (otrzymywanie informacji, opiniowanie,

${ }^{8}$ Por. M. Seweryński, Pojęcie i ideologia partycypacji pracowników w zarzadzaniu przedsiębiorstwem kapitalistycznym - zarys problematyki, "Studia Prawno-Ekonomiczne" 1989, t. XLII, s. 35 i nast.; idem, Perspektywy partycypacji pracowników w zarzadzaniu przedsiębiorstwem..., s. 10 i nast.

${ }^{9}$ Por. T. Wyka, Europejskie standardy $w$ dziedzinie bezpieczeństwa $i$ ochrony zdrowia pracowników a polskie rozwiazania prawne, [w:] Europejskie prawo pracy i prawo socjalne, red. H. Szurgacz, Wrocław 1998, s. 185 i nast. z cyt. tam literaturą zachodnia; J. F. Stöckli, Betriebliche Arbeitnehmervertretung im schweizerischen und im europäischen Recht, "Rechtder Arbeit” 2001, Nr. 5, s. 5-12.

10 Por. J. Wratny w: Prawo pracy RP w obliczu przemian..., s. 512 i nast.

11 Por. J. Wratny, Zasada informacji konsultacji pracowniczej w prawie europejskim. Uwagi dotyczace implementacji prawa europejskiego do prawa polskiego, [w:] Informowanie i konsultacja pracowników w polskim prawie pracy, red. A. Sobczyk, Kraków 2006, s. 9 i nast.; M. Seweryński, Pojęcie i ideologia partycypacji pracowników..., s. 40 i nast.

${ }^{12}$ DzUrz UE C 83 z 30.03.2010, s. 47.

${ }^{13}$ Por. M. Smusz-Kulesza, Zbiorowe prawo pracowników do informacji, Warszawa 2012, s. 33. 
kontrolowanie, współdecydowanie, samodzielne decydowanie) oraz ich udział w wypracowanych efektach (partycypacja finansowa wraz $\mathrm{z}$ akcjonariatem pracowniczym $)^{14}$.

Jednak $\mathrm{w}$ różnych zakładach pracy różne są zakres, zasady i formy prawne tego udziału, co wynika z odrębnych ustaw. Postacie partycypacji wymagają bowiem konkretyzacji w odrębnych ustawach, ponieważ z samej zasady partycypacji, zawartej w art. 182 k.p., trudno skonstruować roszczenie o udział pracowników w zarządzaniu zakładem pracy ${ }^{15}$.

W pojęciu „uczestnictwa pracowników w zarządzaniu zakładem pracy" mieszczą się więc różne formy wyodrębnione w zależności od przyjętego kryterium. Istotne znaczenie ma podział partycypacji na pośrednią (przedstawicielską związkową i pozazwiązkową), rozumianą jako sposób instytucjonalnego uczestnictwa pracowników, poprzez utworzoną reprezentację oraz bezpośrednią, ujmowaną najczęściej jako metoda zarządzania ludźmi w firmie. Ta ostatnia forma odnosi się do bezpośredniego udziału indywidualnych pracowników lub ich grup w zarządzaniu firmą poprzez twórcze i samodzielne działania w zakresie stanowiska pracy czy współuczestnictwo w podejmowaniu decyzji ${ }^{16}$.

3. Dla prywatnych zakładów pracy o różnej wielkości szczególnie ważne znaczenie ma tzw. partycypacja finansowa jako jedna $\mathrm{z}$ istotnym form uczestnictwa pracowników $\mathrm{w}$ zarządzaniu zakładem pracy. W szerokim ujęciu oznacza ona udział pracowników w zyskach i własności poprzez różne formy - od nabywania akcji przedsiębiorstwa przez pracowników po spółdzielczośćc ${ }^{17}$. Znajduje ona jednak obecnie w Polsce bardzo ograniczone zastosowanie. De lege lata forma ta wiąże się z udziałem pracowników w zarządzaniu przedsiębiorstwem $\mathrm{z}$ racji posiadanych praw korporacyjnych związanych z uzyskaniem akcji lub udziałów. W szczególności w spółkach kapitałowych powstałych w wyniku komercjalizacji przedsiębiorstwa państwowego partycypacja pracownicza przybiera postać udziału przedstawicieli pracowników w radzie nadzorczej (2/5 skła-

${ }^{14}$ Por. J. Wratny, Udział pracowników w zarzadzaniu przedsiębiorstwami w krajach Wspólnoty Europejskiej, „Praca i Zabezpieczenie Społeczne” 1993, nr 7, s. 1; M. Gładoch, Uczestnictwo pracowników w zarządzaniu zakładem pracy. Problemy terminologiczne, „Przegląd Prawa Handlowego" 2001, nr 5, s. 32; J. Piwowarczyk, Partycypacja pracownicza i jej klasyfikacja, „Zeszyty Ekonomiczne Akademii Ekonomicznej w Krakowie” 2006, nr 711, s. 64 i nast.

15 Zob. M. Tomaszewska w: Prawo pracy, red. J. Stelina, Warszawa 2013, s. 40.

${ }_{16}$ Zob. A. Giedrewicz-Niewińska, Wptyw wielkości pracodawcy na uczestnictwo pracowników w zarządzaniu zakładem pracy, [w:] Stosunki pracy u małych pracodawców, red. G. Goździewicz, Warszawa 2013, s. 259-261; J. Wąchol, Znaczenie partycypacji pracowniczej w polskiej praktyce nadzoru korporacyjnego a tendencje światowe, [w:] S. Rudolf (red.), Perspektywy rozwoju partycypacji pracowniczej w Polsce w warunkach Unii Europejskiej, Łódź 2007, s. 435 i nast.

17 Zob. A. Giedrewicz-Niewińska, Wpływ wielkości pracodawcy..., s. 261. 
du) jednoosobowej spółki Skarbu Państwa oraz prawa do wybierania jednego przedstawiciela $\mathrm{w}$ zarządzie spółki, jeśli spółka zatrudnia średnio w roku powyżej 500 pracowników.

Nie sposób również pominąć instytucjonalnych form uczestnictwa pracowników w zarządzaniu przedsiębiorstwem państwowym wynikających z ustawy z 25 września 1981 r. o przedsiębiorstwach państwowych ${ }^{18}$ oraz z ustawy z 25 września 1981 r. o samorządzie załogi przedsiębiorstwa państwowego ${ }^{19}$, polegających na udziale przedstawicielstwa pracowniczego (rady pracowniczej i zebrania ogólnego pracowników) w zarządzaniu przedsiębiorstwem państwowym. Pierwotnie organy przedstawicielskie załóg przedsiębiorstw państwowych uzyskały w tych aktach status organów o dość szerokich kompetencjach w dziedzinie zarządzania przedsiębiorstwem wespół z dyrektorem. Obecnie kompetencje te zostały w wyniku kolejnych nowelizacji ograniczone. Przedsiębiorstw państwowych jest także coraz mniej, ponieważ uległy one prywatyzacji, nierzadko w wyniku korupcyjnych praktyk prywatyzacyjnych ${ }^{20}$. Do tych organów należą uprawnienia stanowiące, kontrolne oraz opiniodawcze w określonych ustawą sprawach gospodarczych i pracowniczych.

Nowymi formami partycypacji instytucjonalnej w Polsce są rady pracowników tworzone na zasadach określonych w ustawie z 7 kwietnia 2007 r. o informowaniu pracowników i przeprowadzaniu z nimi konsulta$\mathrm{cji}^{21}$, implementującej dyrektywę nr 2002/14 z 11 marca 2002 r. ustanawiającą ramowe warunki informowania i przeprowadzania konsultacji z pracownikami we Wspólnocie Europejskiej ${ }^{22}$, a także w ustawie z 5 kwietnia 2002 r. o europejskich radach zakładowych ${ }^{23}$, wdrażającej dyrektywę nr 94/45/WE z 22 września 1994 r. w sprawie ustanowienia Europejskiej Rady Zakładowej lub trybu informowania bądź konsultowania pracowników w przedsiębiorstwach albo grupach przedsiębiorstw o zasięgu wspólnotowym ${ }^{24}$. W przeciwieństwie do wyżej przedstawionych form partycypacji pracowniczej aktywnej (silniejszej), realizowanych na zasadzie współzarządzania, formy te dotyczą jedynie pasywnej formy partycypacji, realizowanej na zasadzie współdecydowania ${ }^{25}$. Uprawnienia rad pracowników oraz europejskich rad zakładowych są bowiem mocno

18 T.j. z 2002, nr 112, poz. 981 ze zm.

19 DzU, 1981, nr 24, poz. 123 ze zm.

${ }^{20}$ Por. M. Gajowiak, Kapitał społeczny. Przypadek Polski, Warszawa 2012, s. 107 i nast.

${ }^{21} \mathrm{DzU}, 2007, \mathrm{nr} 79$, poz. 550 ze zm.

22 DzUrz WEL, 2002, nr 80 z 23.03.2002, s. 29.

${ }^{23} \mathrm{DzU}, 2002, \mathrm{nr} 62$, poz. 556 ze zm.

${ }^{24}$ DzUrz WEL, 1994, nr 254 z 30.09.1994, s. 64.

${ }_{25}$ Zob. M. Gładoch, Ustawa o informowaniu pracowników i przeprowadzaniu z nimi konsultacji. Komentarz, Torun 2007, s. 53. 
ograniczone, ponieważ rady te mają wyłącznie kompetencje informacyjno-konsultacyjne ${ }^{26}$, a pozbawione są kompetencji stanowiących. Podobny model partycypacji przyjęty został w spółce europejskiej na mocy ustawy z 4 marca 2005 r. o europejskim zgrupowaniu interesów gospodarczych i spółce europejskiej ${ }^{27}$ oraz w spółdzielni europejskiej na mocy ustawy z 22 lipca 2006 r. o spółdzielni europejskiej ${ }^{28}$. Inną instytucją jest wywodzący się z tradycji brytyjskich rzecznik załogi (zakładowy delegat pracowników) wybierany przez pracowników w tych zakładach pracy, gdzie nie został utworzony związek zawodowy, o którym wspomina projekt zbiorowego kodeksu pracy.

Nowe formy partycypacji instytucjonalnej w Polsce nawiązują do technokratyczno-menedżerskiego stylu zarządzania gospodarką, gdzie udział pracowników w zarządzaniu przedsiębiorstwem polega jedynie na wykonywaniu przez załogę praw do informacyjno-konsultacyjnego wyrażania swych poglądów w sprawach pozostawionych do decyzji dyrektora, zarządu lub innych organów wykonawczych. Ten model partycypacji jako daleko niewystarczający został już w starszej literaturze prawa pracy poddany konstruktywnej krytyce ${ }^{29}$.

Według koncepcji zawartej w porozumieniach gdańskich z roku 1980, opowiadającej się za pełną samodzielnością uspołecznionych zakładów pracy, ustrój gospodarczy Polski w sektorze publicznym miał opierać się na tzw. przedsiębiorstwach społecznych zarządzanych przez rady pracownicze, do których kompetencji należałoby samodzielne dysponowanie powierzonym majątkiem na zasadzie tzw. własności powierniczej oraz powoływanie i odwoływanie dyrektorów jako wykonawców uchwał samorządu pracowniczego i organizatorów pracy załogi ${ }^{30}$. Koncepcja ta w warunkach postsocjalistycznego ustroju pracy w Polsce, uwłaszczenia się nomenklatury, wyprzedaży majątku narodowego oraz wszechobecnej korupcji nie przyjęła się i na zasadach powszechności nie została wcielona w życie w przedsiębiorstwach państwowych, choć pewne jej elementy funkcjonowały już w Polsce w sektorze publicznym w okresie międzywojennym. Idea samorządu pracowniczego będącego niezbędnym

${ }^{26}$ Por. W. Perdeus w: Kodeks pracy. Komentarz, Warszawa 2012, s. 116-118; A. Sobczyk, Rady pracowników. Komentarz, Warszawa 2007, s. 81 i nast.

${ }^{27} \mathrm{DzU}, 2005, \mathrm{nr} 62$, poz. 551 ze zm.

${ }^{28}$ DzU, 2006, nr 149, poz. 1077 ze zm.; R. Pakla, Uczestnictwo pracowników w zarzadzaniu jako fundament europejskiego prawa pracy na przykładzie Spótdzielni Europejskiej, „Jurysta” 2013, nr 12, s. 30 i nast.

${ }_{29}$ Por. W. Szubert, Kierunki rozwoju zbiorowego prawa pracy, „Państwo i Prawo” 1981, nr 6, s. 24; T. Zieliński, Prawo pracy a reforma gospodarcza, „Państwo i Prawo” 1981, nr 9, passim.

${ }^{30}$ Zob. T. Zieliński, Zarys wykładu prawa pracy, cz. III, z. 2, Katowice 1984, s. 245. 
czynnikiem demokratyzacji stosunków społecznych i podstawową przesłanką odnowy gospodarczej, opartej na samodzielności przedsiębiorstw państwowych, okazała się bowiem niezwykle trudna do zrealizowania wskutek kryzysu społecznego, na który złożyły się nie tylko elementy załamania gospodarczego, lecz również ostre konflikty politycznej natury ${ }^{31}$.

4. Kolejne nowelizacje przepisów prawa nie tylko nie rozwinęły, ale nawet ograniczyły zasadę partycypacji pracowników, a zwłaszcza udziału pracowników w zakresie stanowienia odpowiednich warunków pracy. W świetle powyższych wywodów można wysnuć wniosek, że w naszym kraju de lege lata można jednak nadal mówić jedynie o pewnych elementach „partycypacji pracowniczej” rozproszonych w różnych aktach prawnych. Dotychczasowe regulacje prawne mają charakter niepełny i fragmentaryczny. Brak instytucjonalnych rozwiązań w tym zakresie przypisuje się przede wszystkim specyficznym uwarunkowaniom reprezentacji praw i interesów w Polsce, gdzie dominującą rolę odgrywają związki zawodowe z szeroko rozbudowanymi uprawnieniami na szczeblu zakładowym ${ }^{32}$.

Unijne dyrektywy regulujące pracownicze prawo do informacji i konsultacji w pełni uznają prawo pracowników do tworzenia w zakładzie pracy przedstawicielstwa pozazwiązkowego, pozostawiając określenie formy tego przedstawicielstwa prawu krajowemu, nie wykluczając przy tym żadnej z nich. Prawo europejskie dopuszcza obie formy - związkową i pozazwiązkową - w partycypacji osób zatrudnionych w zarządzaniu przedsiębiorstwem ${ }^{33}$. De lege lata w Polsce dominują jednak formy uczestnictwa pracowników w zarządzaniu o charakterze informacyjno-konsultacyjnym, cechujące się niskim poziomem ingerencji przedstawicielstwa pracowniczego w decyzje pracodawcy, co jest charakterystyczne dla gospodarki rynkowej $^{34}$. Idea partycypacji pracowniczej w obecnym kształcie ustawowym nie jest więc dla pracowników atrakcyjna. Należy mieć nadzieję, że w przyszłości kompetencje pozazwiązkowego przedstawicielstwa pracowniczego będą miały także charakter stanowiąco-kontrolny. W związku z tym będzie można mówić o prawdziwej partycypacji pracowniczej. Należy dążyć do tego, by kompetencje przedstawicielstwa pracowniczego znacznie

31 Ibidem, s. 329-330.

32 Zob. G. Goździewicz, Podstawowe zasady zbiorowego prawa pracy, [w:] Zbiorowe prawo pracy w społecznej gospodarce rynkowej, red. G. Goździewicz, wyd. TNOiK, Toruń 2000, s. 83; M. Rycak, Aksjologiczne podstawy partycypacji pracowniczej w zarządzaniu przedsiębiorstwem, [w:] Zakładowy dialog społeczny, red. J. Stelina, Warszawa 2014, s. 314 i nast.

${ }_{33}$ Zob. M. Seweryński, Wybrane problemy konstytucyjne kodyfikacji prawa pracy, [w:] Konstytucyjne problemy prawa pracy i zabezpieczenia społecznego, red. H. Szurgacz, Wrocław 2005, s. 21, 22.

${ }^{34}$ Por. K.W. Baran w: Kodeks pracy 2011. Komentarz, red. B. Wagner, Gdańsk 2011, s. 95. 
wykraczały poza działalność informacyjno-konsultacyjną pracowników. Dopiero poszerzenie zakresu jego kompetencji o istotne uprawnienia natury stanowiącej przyczyni się do oparcia zbiorowego prawa pracy w Polsce na zasadzie realnego współzarządzania pracowniczego ${ }^{35}$. Trudno również uznać samorząd załogi przedsiębiorstw państwowych za relikt przeszłości, ponieważ jest to jak dotychczas najbardziej rozwinięta forma instytucjonalna partycypacji pracowniczej $\mathrm{w}$ Polsce, $\mathrm{z}$ uprawnieniami stanowiącymi w niektórych sprawach określonych ustawą. Jednak większość przedsiębiorstw państwowych została sprywatyzowana i w związku z tym rola samorządów załogi uległa marginalizacji.

Powszechnie praktykowany na Zachodzie Europy akcjonariat pracowniczy oraz rozwój spółdzielczości sprzyjają w warunkach kryzysu ekonomicznemu rozwojowi przedsiębiorstw. W Polsce, niestety, akcjonariat pracowniczy istnieje $\mathrm{w}$ szczątkowej formie, ponieważ partycypacja związana $\mathrm{z}$ akcjonariatem pracowniczym okazała się nieskuteczna. Ze względu na uwarunkowania prawne $\mathrm{w}$ przypadku prywatyzacji kapitałowej niewiele akcji trafiło w ręce pracowników, z których większość była i tak zainteresowana ich korzystnym zbyciem. Tymczasem akcjonariat pracowniczy stanowi rozwiniętą formę partycypacji pracowników w zarządzaniu zakładem pracy prawie nie wykorzystaną w naszym kraju ${ }^{36}$. 534 Partycypacji finansowej w formie akcjonariatu pracowniczego nie sprzyja też dopuszczenie do publicznego obrotu akcji nabywanych preferencyjnie przez pracowników po krótkim okresie wyłączenia ich z obrotu ${ }^{37}$.

Również rozwój spółek pracowniczych tzw. leasingowych napotkał w praktyce bariery prawne i kapitałowe. Większość z tych spółek okazała się tylko tworami przejściowymi, które przekształciły się w spółki menedżersko-inwestorskie i inne o kapitale prywatnym. W przypadku leasingu pracowniczego mało firm zachowało rozproszony akcjonariat wśród pracowników. Stosunkowo szybko nastąpiła koncentracja własności albo wśród dotychczasowego kierownictwa, albo przejął je inwestor zewnętrzny ${ }^{38}$. Zaprzepaszczono pozytywne doświadczenia akcjonariatu

${ }^{35}$ Por. W. Sanetra, Kilka refleksji o przyszłości prawa pracy, „Praca i Zabezpieczenie Społeczne" 2006, nr 1, s. 2 i nast.; M. Gładoch, Uczestnictwo pracowników zarządzaniu z perspektywy prawa wspólnotowego, [w:] Europeizacja polskiego prawa pracy, red. W. Sanetra, Warszawa 2004, s. 155 i nast.

36 Por. J. Wratny, Akcjonariat pracowniczy w świetle badań w przedsiębiorstwach sprywatyzowanych, „Praca i Zabezpieczenie Społeczne” 2005, nr 5, s. 8-13; M. Leski, Akcjonariat pracowniczy w Polsce, „Praca i Zabezpieczenie Społeczne” 2012, nr 8, s. 7-15.

37 Zob. J. Wratny, Partycypacja pracownicza w warunkach gospodarki rynkowej w Polsce, [w:] Zbiorowe prawo pracy w społecznej gospodarce rynkowej, red. G. Goździewicz, Torun 2000, s. 204-205.

${ }^{38}$ Por. M. Bednarski, Partycypacja pracownicza w prywatyzowanych polskich przedsiębiorstwach a zatrudnienie, „Polityka Społeczna” 2005, nr 5-6, s. 5-6. 
pracowniczego $\mathrm{w}$ Polsce $\mathrm{w}$ okresie międzywojennym. Instrumentalne podejście do akcjonariatu pracowniczego doprowadziło do tego, że Polska straciła niepowtarzalną szansę na upowszechnienie własności pracowniczej na początku lat dziewięćdziesiątych wieku XX w warunkach transformacji ustroju i związanych z tym przekształceń własnościowych. Nadal bowiem kwestie rozwoju własności pracowniczej regulowane są na szczeblu krajowym, a perspektywa przyjęcia wspólnych ram prawnych dla całej Unii Europejskiej jest jak na razie dość odległa. Działania podejmowane przez kolejne polskie rządy oraz parlament są jak na razie daleko niewystarczające, zwłaszcza jeśli chodzi o mocniejsze formy partycypacji, a zwłaszcza akcjonariat pracowniczy. Trudno zatem mówić o realizacji wytycznej legislacyjnej zawartej w podstawowej zasadzie prawa pracy zawartej w art. $18^{2} \mathrm{k}$.p. stanowiącej o uczestnictwie pracowników w zarządzaniu zakładem pracy ${ }^{39}$. Należy zatem wysunąć postulat de lege ferenda kompleksowego uregulowania akcjonariatu pracowniczego na wzór podobnych regulacji w innych $\mathrm{krajach}^{40}$. Wymaga to jednak zmiany nie tylko prawa pracy, ale również prawa podatkowego, finansowego i ubezpieczeniowego, a także cywilnego i handlowego.

Zasady uczestnictwa pracowników w organach spółek kapitałowych powstałych $\mathrm{z}$ przekształcenia przedsiębiorstw państwowych $\mathrm{w}$ formie przedstawicielstwa $\mathrm{w}$ radach nadzorczych wymagają również udoskonalenia jako nie do końca przemyślane. Podobnie nie przyjęło się powszechnie $\mathrm{w}$ Polsce stosowanie bezpośrednich form partycypacji pracowniczej, np. zakładanie kół jakości, grupowa organizacja pracy. Ze względu na to, że partycypacja pośrednia właściwie nie występuje u małych pracodawców, istotną rolę w tych przypadkach może odgrywać partycypacja bezpośrednia, na którą składają się rozwiązania ujęte w obowiązujących przepisach, np. z zakresu bhp, jak i wytworzone w praktyce (pozaprawne). Natomiast $\mathrm{w}$ przedsiębiorstwach średnich, nieuzwiązkowionych należy podkreślić znaczenie delegata załogi, o którym mowa w projekcie zbiorowego kodeksu pracy ${ }^{41}$.

5. Należy promować wszelkie formy uczestnictwa pracowników w zarządzaniu firmą wynikające $\mathrm{z}$ otwartego, partycypacyjnego stylu zarządzania $^{42}$. Uczestnictwo pracowników w zarządzaniu przedsiębiorstwem

${ }^{39}$ Por. J. Wratny w: System prawa pracy. Zbiorowe prawo pracy, t. V, red. K.W. Baran, Warszawa 2014, s. 911.

${ }^{40}$ Por. L. Gilejko, Partycypacja i akcjonariat pracowniczy w Polsce. Stan i perspektywy, Warszawa 1995, s. 8 i nast.; J. Lowitzsch, Partycypacja finansowa w społecznej gospodarce rynkowej Unii Europejskiej. Podejście modułowe, Franfurt nad Odrą-Kraków 2011, passim; M. Leski, Akcjonariat pracowniczy w Polsce, „Praca i Zabezpieczenie Społeczne” 2012, nr 8, s. 7 i nast.

${ }^{41}$ Zob. A. Giedrewicz-Niewińska, Wpływ wielkości pracodawcy..., s. 276-277.

${ }^{42}$ Por. P. Zientara, Przesłanki i formy partycypacji pracowniczej w największych gospodarkach (Niemcy, Francja, Wielka Brytania), „Wspólnoty Europejskie” 2006, nr 10, s. 40-48. 
jest obecnie powszechnym zjawiskiem w krajach o rozwiniętych gospodarkach. Korzyści płynące z partycypacji pracowniczej dostrzega nie tylko katolicka nauka Kościoła ${ }^{43}$, ale również doktryna liberalna ${ }^{44}$. Stąd rozwój partycypacji w takich krajach, jak Francja oraz Stany Zjednoczone. Partycypacyjny styl zarządzania jest obecnie najbardziej efektywną metodą zarządzania przedsiębiorstwem. Dotyczy to również przedsiębiorstw publicznych (państwowych i samorządowych) oraz spółdzielni.

Zbudowanie nowego modelu partycypacji pracowników w zarządzaniu nie będzie jednak $\mathrm{w}$ naszym społeczeństwie łatwe, ponieważ zależy ono od poziomu wiedzy i umiejętności oraz kultury pracowników, kadry kierowniczej, a także woli elit politycznych ${ }^{45}$. Konieczna jest również zmiana prawa podatkowego i finansowego, które aktualnie nie uwzględnia nowoczesnych metod zarządzania przedsiębiorstwami publicznymi i prywatnymi.

\section{Bibliografia}

Baran K.W. w: Kodeks pracy 2011. Komentarz, red. B. Wagner, Gdańsk 2011.

Bednarski M., Partycypacja pracownicza w prywatyzowanych polskich przedsiębiorstwach a zatrudnienie, „Polityka Społeczna” 2005, nr 5-6.

Gajowiak M., Kapitat społeczny. Przypadek Polski, Warszawa 2012.

Giedrewicz-Niewińska A., Wpływ wielkości pracodawcy na uczestnictwo pracowników w zarzadzaniu zakładem pracy, [w:] Stosunki pracy u małych pracodawców, red. G. Goździewicz, Warszawa 2013.

Gilejko L., Partycypacja i akcjonariat pracowniczy w Polsce. Stan i perspektywy, Warszawa 1995.

Gładoch M., Uczestnictwo pracowników w zarządzaniu z perspektywy prawa wspólnotowego, [w:] Europeizacja polskiego prawa pracy, red. W. Sanetra, Warszawa 2004.

Gładoch M., Uczestnictwo pracowników w zarzadzaniu zakładem pracy. Problemy terminologiczne, „Przegląd Prawa Handlowego” 2001, nr 5.

Gładoch M., Ustawa o informowaniu pracowników i przeprowadzaniu z nimi konsultacji. Komentarz, Toruń 2007.

Jończyk J., Problemy pracowniczego wspótzarzadzania, [w:] Pracownicze wspótzarządzanie, Wrocław 1980.

Juchnowicz M., Partycypacja jako narzędzie polityki personalnej, [w:] Zarządzanie pracownikami instrumenty polityki personalnej, red. K. Makowski, Warszawa 2001.

Leski M., Akcjonariat pracowniczy w Polsce, „Praca i Zabezpieczenie Społeczne” 2012, nr 8.

Liszcz T., Prawo pracy, Warszawa 2009;

${ }^{43}$ Por. M. Moczydłowski, Podstawy partycypacji pracowników w zyskach z perspektywy nauczania społecznego Kościoła, [w:] Humanizacja pracy w warunkach współczesnego ładu gospodarczego, red. K. Kubala, Ł. Kutyło, Łódź 2014, s. 103 i nast.

${ }^{44}$ Por. T. Mendel, Partycypacja w zarządzaniu współczesnymi organizacjami, Poznań 2002, s. 103 i nast.

${ }^{45}$ Por. J. Jończyk, Problemy pracowniczego wspótzarzadzania, [w:] Pracownicze współzarzadzanie, Wrocław 1980, s. 17 i nast. 
Lowitzsch J., Partycypacja finansowa w społecznej gospodarce rynkowej Unii Europejskiej. Podejście modutowe, Frankfurt nad Odrą-Kraków 2011.

Mendel T., Partycypacja w zarządzaniu współczesnymi organizacjami, Poznań 2002.

Moczydłowski M., Podstawy partycypacji pracowników w zyskach z perspektywy nauczania społecznego Kościoła, [w:] Humanizacja pracy w warunkach wspótczesnego ładu gospodarczego, red. K. Kubala, Ł. Kutyło, Łódź 2014.

Pakla R., Uczestnictwo pracowników w zarządzaniu jako fundament europejskiego prawa pracy na przykładzie Spółdzielni Europejskiej, ,Jurysta” 2013, nr 12.

Perdeus W. w: Kodeks pracy. Komentarz, Warszawa 2012, s. 116-118.

Piwowarczyk J., Partycypacja pracownicza i jej klasyfikacja, „Zeszyty Ekonomiczne Akademii Ekonomicznej w Krakowie" 2006, nr 711.

Piwowarczyk J., Partycypacja w zarzadzaniu a motywowanie pracowników, Kraków 2006.

Rycak M., Aksjologiczne podstawy partycypacji pracowniczej w zarzadzaniu przedsiębiorstwem, [w:] Zakładowy dialog społeczny, red. J. Stelina, Warszawa 2014.

Sanetra W., Kilka refleksji o przyszłości prawa pracy, „Praca i Zabezpieczenie Społeczne” 2006, nr 1.

Seweryński M., Perspektywy partycypacji pracowników w zarządzaniu przedsiębiorstwem w krajach zachodnich, "Studia Prawno-Ekonomiczne” 1992, nr 46.

Seweryński M., Pojęcie i ideologia partycypacji pracowników w zarządzaniu przedsiębiorstwem kapitalistycznym - zarys problematyki, „Studia Prawno-Ekonomiczne” [Łódź] 1989, t. XLII.

Seweryński M., Wybrane problemy konstytucyjne kodyfikacji prawa pracy, [w:] Konstytucyjne problemy prawa pracy i zabezpieczenia społecznego, red. H. Szurgacz, Wrocław 2005.

Smusz-Kulesza M., Zbiorowe prawo pracowników do informacji, Warszawa 2012.

Sobczyk A., Rady pracowników. Komentarz, Warszawa 2007.

Stöckli J.F., Betriebliche Arbeitnehmervertretung im schweizerischen und im europäischen Recht, „Recht der Arbeit” 2001, Nr. 5.

Szubert W., Kierunki rozwoju zbiorowego prawa pracy, „Państwo i Prawo” 1981, nr 6.

Tomaszewska M. w: Prawo pracy, red. J. Stelina, Warszawa 2013.

Wąchol J., Znaczenie partycypacji pracowniczej w polskiej praktyce nadzoru korporacyjnego a tendencje światowe, [w:] S. Rudolf (red.), Perspektywy rozwoju partycypacji pracowniczej w Polsce w warunkach Unii Europejskiej, Łódź 2007.

Wojtaszczyk K., Partycypacja pracowników w zarządzaniu. Model austriacki i zachodnioniemiecki, Warszawa 1982.

Wratny J., Akcjonariat pracowniczy w świetle badań w przedsiębiorstwach sprywatyzowanych, „Praca i Zabezpieczenie Społeczne” 2005, nr 5.

Wratny J., Partycypacja pracownicza w warunkach gospodarki rynkowej w Polsce, [w:] Zbiorowe prawo pracy w społecznej gospodarce rynkowej, red. G. Goździewicz, Torun 2000.

Wratny J., Problemy partycypacji przedstawicielskiej, [w:] Prawo pracy RP w obliczu przemian, M. Matey-Tyrowicz, T. Zieliński, Warszawa 2006.

Wratny J., Udział pracowników w zarządzaniu przedsiębiorstwami w krajach Wspólnoty Europejskiej, „Praca i Zabezpieczenie Społeczne” 1993, nr 7.

Wratny J. w: System prawa pracy. Zbiorowe prawo pracy, t. V, red. K.W. Baran, Warszawa 2014.

Wratny J., Zasada informacji i konsultacji pracowniczej w prawie europejskim. Uwagi dotyczace implementacji prawa europejskiego do prawa polskiego, [w:] Informowanie i konsultacja pracowników w polskim prawie pracy, red. A. Sobczyk, Kraków 2006.

Wyka T., Europejskie standardy w dziedzinie bezpieczeństwa i ochrony zdrowia pracowników a polskie rozwiazania prawne, [w:] Europejskie prawo pracy i prawo socjalne, red. H. Szurgacz, Wrocław 1998. 
Zieliński T., Prawo pracy a reforma gospodarcza, „Państwo i Prawo” 1981, nr 9.

Zieliński T., Prawo pracy. Zarys systemu, t. III, Warszawa-Kraków 1986.

Zieliński T., Zarys wykładu prawa pracy, cz. III, z. 2, Katowice 1984.

Zientara P., Przestanki i formy partycypacji pracowniczej w największych gospodarkach (Niemcy, Francja, Wielka Brytania), „Wspólnoty Europejskie” 2006, nr 10.

\section{Employee Participation as the Future of Collective Labour Law}

\section{Summary}

One of the basic principles of labour law in Poland is the principle of participation of employed persons in the management of the workplace. Participatory management style is currently the most effective method of enterprise management. This applies particularly to public enterprises (state and local government) and cooperatives. We should promote all forms of employee participation in the management of the company resulting from an open, participatory management style. Employee participation in enterprise management is now a common phenomenon in countries with developed economies.

In our country, we can speak de lege lata only about certain elements of "employee participation" scattered in different legal acts. Existing regulations are incomplete and fragmentary. Lack of institutional solutions in this regard is primarily attributed to specific determinants of representing the rights and interests of employees in Poland. Building a new model of employee participation in management will not be easy in our society, because it depends on the level of knowledge, skills and culture of employees, executives and the will of political elites. 